\title{
Host Soluble Mediators: Defying the Immunological Inertness of Aspergillus fumigatus Conidia
}

\author{
Sarah Sze Wah Wong * and Vishukumar Aimanianda * \\ Unité des Aspergillus, Department of Mycology, Institut Pasteur, 75015 Paris, France \\ * Correspondance: swong@pasteur.fr (S.S.W.W.); vkumar@pasteur.fr (V.A.); \\ Tel.: +33-1-45-68-82-25 (S.S.W.W. \& V.A.)
}

Received: 22 November 2017; Accepted: 22 December 2017; Published: 24 December 2017

\begin{abstract}
Aspergillus fumigatus produce airborne spores (conidia), which are inhaled in abundant quantity. In an immunocompromised population, the host immune system fails to clear the inhaled conidia, which then germinate and invade, leading to pulmonary aspergillosis. In an immunocompetent population, the inhaled conidia are efficiently cleared by the host immune system. Soluble mediators of the innate immunity, that involve the complement system, acute-phase proteins, antimicrobial peptides and cytokines, are often considered to play a complementary role in the defense of the fungal pathogen. In fact, the soluble mediators are essential in achieving an efficient clearance of the dormant conidia, which is the morphotype of the fungus upon inhalation by the host. Importantly, harnessing the host soluble mediators challenges the immunological inertness of the dormant conidia due to the presence of the rodlet and melanin layers. In the review, we summarized the major soluble mediators in the lung that are involved in the recognition of the dormant conidia. This knowledge is essential in the complete understanding of the immune defense against A. fumigatus.
\end{abstract}

Keywords: Aspergillus fumigatus; innate immunity; humoral immunity; complement

\section{Introduction}

Aspergillus fumigatus is a ubiquitous fungus that produces spores, called "conidia", through asexual reproduction [1]. These conidia are small-sized $(2-3 \mu \mathrm{m})$ and encased with a hydrophobic cell wall and are, therefore, airborne [2]. This opportunistic fungal pathogen can cause a range of infections. For instance, invasive pulmonary aspergillosis under immunocompromised status, chronic pulmonary aspergillosis, and allergic bronchopulmonary aspergillosis in populations with underlying pulmonary dysfunctions [3]. In otherwise healthy populations, the inhaled conidia are efficiently cleared by the immune system and no inflammatory response would be triggered.

Upon inhalation, the conidia (in the dormant morphotype) travel down the airway to reach the lung cavity, where they would be cleared by alveolar macrophages and neutrophils. The recognition of the conidia by the immune cells are challenged by the presence of the rodlet and melanin layers of the outer cell wall of $A$. fumigatus that masks the immunogenic polysaccharides in the inner cell wall $[4,5]$. The rodlet layer is composed of mainly the hydrophobic protein RodA, whereas melanin layer is present underneath the rodlet layer [6]. As the conidia swell, this rodlet and melanin layers are shed, exposing the polysaccharides in the inner cell wall that contains polysaccharides ( $\beta$-glucan, $\alpha$-glucan, chitin, and galactomannan).

However, dormant conidia are phagocytosed despite the shielding of the immunogenic polysaccharides by the rodlet and melanin layers. The immune receptors recognizing fungal cell wall polysaccharides are comparatively well studied, but these cell wall polysaccharides in dormant conidia are not easily accessible to the immune receptors because of the rodlet-melanin layers. The role of soluble mediators in the antifungal defense has been neglected but it is crucial in the efficient clearance 
of conidia in the early stage of host immune defense as they are the first components to interact with $A$. fumigatus spores before the innate immune cells. Soluble mediators, including complement system, acute-phase proteins, antimicrobial peptides, and cytokines, constitute an integral part of innate immune response [7]. The responsible soluble mediators involved in the immune recognition of dormant $A$. fumigatus conidia are mainly related to complement components and acute-phase proteins, which would be discussed in the following sections. Antimicrobial peptides and cytokines are not involved in the immune recognition of dormant conidia, but rather, contribute to the clearance of conidia by other means. Antimicrobial peptides exert direct antifungal activities on the A. fumigatus or enhance the intracellular killing by immune cells [8-10], while, cytokines impose pro-inflammatory response by recruiting immune cells or modulating their antifungal activities [8].

This review will summarize the soluble mediators that are known to bind to the dormant conidial surface of A. fumigatus and bridge the immune recognition of dormant conidia which challenge their immunological inertness (summarized in Table 1). It is important to elucidate (1) the soluble mediators that bind to the surface of the dormant A. fumigatus conidia; (2) to which ligands they are binding; and (3) the immune receptors responsible for the opsonin-mediated recognition.

\section{Complement Components Associated with Recognition of Dormant Conidia}

The complement system is a humoral arm of innate immunity that consists of the classical, lectin, and alternative pathways [11]. The three pathways are activated by the binding of distinct pattern-recognition molecules on the pathogen surface, forming complement component $\mathrm{C} 3$ convertase. The alternative pathway starts with the auto-hydrolysis of C3 into C3b. Immunoglobulin has also been demonstrated to activate alternative pathway [12]. Classical pathway is antibody-mediated that starts with the binding of IgM or IgG on the microbial surface. The lectin pathway is activated by the binding of mannose-binding lectin or ficolin, that interact with serine proteases (MASPs), on the pathogen surface [13]. The C3 convertase cleaves $\mathrm{C} 3$ into opsonins $\mathrm{C} 3 \mathrm{~b}$ or iC $3 \mathrm{~b}$ (inactivated form of $\mathrm{C} 3 \mathrm{~b}$ that is incapable of amplifying). The cascade then continues to achieve the three main ultimate goals, as follows: (1) opsonization by C3b and iC3b; (2) recruitment of immune cells by production of anaphalytoxins $\mathrm{C} 3 \mathrm{a}$ and $\mathrm{C} 5 \mathrm{a}$; and (3) direct lytic killing of the pathogen by formation of membrane attack complex (MAC). However, due to the presence of a thick fungal cell wall, the MAC is unlikely to kill the fungi by membrane lysis; therefore, the importance of complement system on antifungal defense has always been overlooked. In fact, the complement system is crucial in enhancing immune recognition of the conidia via opsonization [14], in particular, for the dormant conidia.

Many studies have demonstrated that dormant conidia activate mainly the alternative pathway, while there is a growing activation of classical pathway as the conidia swell and germinate [15-17]. The major complement component $\mathrm{C} 3$ has been shown to bind to the surface of A. fumigatus conidia and mycelia $[15,18]$. The surface bound C3 is rapidly converted to the inactivated form iC3b [18]. $\mathrm{iC} 3 \mathrm{~b}$ is the primary form deposited on dormant conidia while there is a mixture for both on swollen and germinating conidia $[15,18]$. iC3b is incapable of the formation of $\mathrm{C} 3$ convertase and, thus, the amplification of $\mathrm{C} 3 \mathrm{~b}$ is halted [11].

Mannose-binding lectin (MBL) is C-type lectin (collectin) that binds to mannose via its carbohydrate recognition domain in a calcium-dependent manner [19]. MBL binds to dormant A. fumigatus conidia $[16,20]$. Ficolin (fibrinogen + collagen + lectin) is another family of lectin that consists of a collagenous domain and a fibrinogen domain that recognizes $\mathrm{N}$-acetylglucosamine (GlcNAc) [21]. There are three ficolins (ficolin-1, ficolin-2, and ficolin-3) in human [21]. Ficolin-2 and ficolin-3 bind to dormant $A$. fumigatus conidia in a calcium-independent manner [22,23]. Normally, in the lectin pathway, MASPs form complexes with MBL or ficolins, and cleaves C4 to form the C3 convertase $(\mathrm{C} 4 \mathrm{bC} 2 \mathrm{a})$ and, thus, activating $\mathrm{C} 3$. However, it has been shown that the MBL bound to A. fumigatus conidia directly activate $\mathrm{C} 3$ without the formation of $\mathrm{C} 4 \mathrm{bC2a}$ [16]. Similar to MBL, ficolin-2 opsonisation of conidia does not lead to $C 4$ deposition, suggesting the absence of lectin pathway activation [24]. Taken together, the lectin pathway is not activated by dormant conidia. 
Instead, the MBL-MASP and/or ficolin-MASP complexes bound on the conidial surface activate C3 for opsonisation. In fact, MASP can directly activate C3 [11].

The classical pathway is activated by the binding of $\mathrm{C} 1$ complex (consisting of $\mathrm{C} 1 \mathrm{q}, \mathrm{C} 1 \mathrm{r}$, and $\mathrm{C} 1 \mathrm{~s}$ ) to immunoglobulin that bind to the surface antigen of the pathogen [11]. C1q was also shown to bind to dormant conidia in the presence of serum, which leads to activation of C3 [25,26].

It raises the question of the identity of the ligand(s) to which MBL, ficolins and $\mathrm{C} 1 \mathrm{q}$ bind. It was shown that melanin of Cryptoccocus neoformans and Aspergillus niger activate the alternative pathway [27], suggesting that melanin may not be the ligand for MBL, ficolins, and C1q binding. The melanin in C. neoformans and A. niger is synthesized through the DOPA (3,4-dihydroxyphenylalanine) pathway [28,29], while that of A. fumigatus is through the DHN (1,8-dihydroxynaphthalene) pathway [30]. Therefore, it is worth checking the role of DHN melanin in complement activation.

\section{Non-Complement Components Associated with the Recognition of Dormant Conidia}

In addition to the complement components, the acute-phase proteins (APPs) make up another group of soluble mediators. The acute-phase proteins (APPs) are defined as the proteins with significant changes in plasma concentrations in response to the events of infection, inflammation or tissue injury [31]. Cytokines, C-reactive proteins and several complement proteins, for instance, C3, C4, and mannose-binding lectin, are also acute-phase proteins [31].

The lung surfactant proteins A and D (SP-A and SP-D) are collectins (calcium-dependent lectins consisting of collagenous region and a carbohydrate recognition domain) that play a major role in pulmonary immunity [32]. Although they are not classical APPs, the levels of SP-A and SP-D increase following infection or inflammation, for instance, following the inoculation of intratracheal lipopolysaccharide [33], and following allergic airway challenge of A. fumigatus [34]. SP-A and SP-D are crucial to the immune defense against $A$. fumigatus [35]. They bind, with dependency to calcium, to dormant $A$. fumigatus conidia and facilitate phagocytosis and killing by neutrophils and alveolar macrophages [36]. Then, later, another study contrastingly demonstrated that the binding of SP-A and SP-D to dormant A. fumigatus conidia is independent of calcium [37]. This discrepancy leaves the identity of the responsible ligand(s) unclear.

Other recently-discovered collectins, namely, collectin-11 (CL-K1) and collectin-12 (CL-P1), are also demonstrated to bind A. fumigatus conidia in a calcium-dependent manner [38,39]. Similarly to other collectins, the binding of CL-K1 does not lead to complement activation [38].

The pentraxin-related protein 3 (PTX3) is a member of the pentraxin family, which is a pattern-recognition receptor and acute-phase proteins. Ptx3 binds to A. fumigatus conidia through the $\mathrm{N}$-terminal domain, while the $\mathrm{C}$-terminal domain is required for receptor binding [40]. Ptx3-deficient mice are susceptible to invasive aspergillosis [41]. Ptx3 also binds to C1q [42]. Administration of PTX3 to C1q-deficient mice reverses the susceptibility, proving the non-redundant role of PTX3 independent of C1q [41].

A high level of C-reactive protein (CRP) is demonstrated in invasive aspergillosis patients $[43,44]$. $\mathrm{CRP}$ is similar to immunoglobulin $\mathrm{G}$ as they both activate the complement cascade and are recognized by the Fc $\gamma$ receptors [45]. CRP binds to A. fumigatus hyphal fractions [46] and enhances neutrophil phagocytosis of dormant conidia through opsonization [47]. Apart from this information, nothing else is known about the interaction between CRP and dormant $A$. fumigatus conidia, which could not be ignored.

\section{Immune Receptors}

Following the binding of soluble mediators to the conidia, the immune-complex binds to receptors on immune cells to trigger phagocytosis and inflammatory response. The relationship between soluble mediators and immune receptors are not exclusive, but rather, promiscuous. In fact, it is a complex network where one soluble mediator can be recognized by several immune receptors, and vice versa. 


\subsection{Complement Receptors and Fcr Receptors}

The major types of opsonic receptors found on phagocytic cells are Fc $\gamma$ receptors (Fc $\gamma$ Rs) and complement receptors (CR1, CR3, and CR4).

Fc $\gamma$ Rs recognize dormant conidia that are opsonized by IgG or CRP and, thus, promote phagocytosis [45]. Complement receptor 3 (CR3) and complement receptor 4 (CR4) are heterodimeric integrins that share a common $\beta_{2}$ subunit (CD18) and have different $\alpha$ subunits. The $\alpha$ subunits for $\mathrm{CR} 3$ and $\mathrm{CR} 4$ are $\alpha_{\mathrm{M}}(\mathrm{CD} 11 \mathrm{~b})$ and $\alpha_{\mathrm{x}}(\mathrm{CD} 11 \mathrm{c})$, respectively. CR3 recognizes a broad range of ligands, including iC3b, $\beta$-1,3-glucan, Ptx3, and LPS [40,48], while CR4 mainly recognizes iC3b [49]. Although the $\alpha$ subunits of CR3 and CR4 are highly similar, and both CR3 and CR4 bind iC3b, the binding sites involved on $\mathrm{iC} 3 \mathrm{~b}$ for binding to the two CRs are different [50]. In addition, the structure of the cytoplasmic domains of the two CRs are different which may contribute to different downstream signaling pathways [51]. CR3-mediated phagocytosis requires the activation of Rho which then induces actin polymerization [52]. On the other hand, it has shown that CR4 mediates the binding to iC3b-opsonized particles, but the phagocytosis requires the participation of CR3 [53]. Complement receptor 1 (CR1) (CD35) recognizes C3b, C1q, and MBL and mediates phagocytosis of the opsonized particle by activating phospholipase D [54-56]. Importantly, the adhesion and phagocytosis of iC3bor C3b-opsonized particles mediated by complement receptors alone do not trigger the production of respiratory burst, which is required for the intracellular killing of the internalized conidia $[57,58]$. The production of respiratory burst requires the cooperation between CR3 and Fc $\gamma$ RIII [59].

The three main complement receptors also differ in their amount in various cell types [51]. For instance, CR4 is highly expressed on tissue macrophages; in contrast, CR3 and CR1 are slightly expressed. CR3 and CR1 are highly expressed on neutrophils, but CR4 is otherwise slightly expressed. This renders CR4 to have a significant role in the recognition of A. fumigatus conidia, as the alveolar macrophages are the first type of professional phagocytes to encounter the inhaled conidia before the neutrophils. However, the importance of CR4 is unclear as most of the phagocytosis could be largely inhibited by blocking CR3 alone by antibodies [51]. Little is known about the role of these four receptors in the phagocytosis of dormant $A$. fumigatus conidia. Only one study that has contributed to the knowledge that the long pentraxin 3 (Ptx3) opsonizes A. fumigatus conidia and facilitates phagocytosis via the Fc $\gamma$ R and CR3 [40].

\subsection{Calreticulin}

The recognition of the other opsonins, besides $\mathrm{iC} 3 \mathrm{~b}$ and $\mathrm{C} 3 \mathrm{~b}$, of dormant A. fumigatus conidia (C1q, SP-A, SP-D, and MBL) is mediated by the calreticulin-CD91 complex [60,61]. Calreticulin is an intracellular chaperone that lacks a transmembrane domain. By binding to CD91 on macrophage surface, the calreticulin-CD91 complex is able to mediate phagocytic uptake [60]. It was previously believed that calreticulin binds to the collagen-like region of collectins, while the CD91 acts as a transmembrane anchor that then activates signaling transduction for initiating phagocytosis. However, it was later found that $\mathrm{CD} 91$ also directly binds to $\mathrm{C} 1 \mathrm{q}$. In addition, the signaling transduction of phagocytosis by the calreticulin-CD91 complex remained unidentified. SP-A and SP-D bind to calreticulin/CD91 via the collagenous region to initiate a pro-inflammatory response, while they bind $\operatorname{SIRP} \alpha$ via the globular head [62]. 
Table 1. Soluble mediators interacting with A. fumigatus conidia, responsive receptors on effector immune cells involved in their recognition and their proven or possible function.

\begin{tabular}{|c|c|c|c|c|}
\hline Soluble Mediator & Immune Receptor & Effective Immune Cells & Function & Reference \\
\hline $\mathrm{C} 3: \mathrm{C} 3 \mathrm{~b} / \mathrm{iC} 3 \mathrm{~b}$ & $\mathrm{CR} 1, \mathrm{CR} 3, \mathrm{CR} 4$ & $\begin{array}{l}\text { Macrophages, dendritic cells, } \\
\text { neutrophils, monocytes }\end{array}$ & $\begin{array}{l}\mathrm{C} 3 \mathrm{~b} \text { and } \mathrm{iC} 3 \mathrm{~b} \text { opsonizes conidia facilitating phagocytosis } \\
\text { Opsonization interferes with dissemination of } \\
\text { A. fumigatus (antimicrobial effect) }\end{array}$ & {$[14,15,17,18]$} \\
\hline C3: C3d & CR2 (CD35) & B cells & $\begin{array}{l}\text { C3d-opsonized conidia lowers threshold for } \\
\text { B cell activation }\end{array}$ & {$[14]$} \\
\hline $\mathrm{C} 1 \mathrm{q}$ & $\mathrm{C} 1 \mathrm{qR}$ & $\begin{array}{c}\text { Monocytes, } \\
\text { polymorphonuclear leukocytes }\end{array}$ & $\begin{array}{l}\text { Interaction with Ptx } 3 \text { activates classical pathway on } \\
\text { A. fumigatus conidia }\end{array}$ & [63] \\
\hline Ficolin-2 and Ficolin-3 & \multirow{2}{*}{\multicolumn{2}{|c|}{$\begin{array}{l}\text { Their interaction with the immune cells is rather indirect, } \\
\text { through activation of lectin pathway }\end{array}$}} & \multirow{2}{*}{$\begin{array}{l}\text { Form complex with MASPs, activating C3 } \\
\text { Ficolin-2 interacts with Ptx3, activating lectin pathway } \\
\text { MBL has been shown to activate C3 directly } \\
\text { Ficolin-3 opsonizes conidia and activates lectin pathway }\end{array}$} & {$[23,64]$} \\
\hline Mannose-binding lectin (MBL) & & & & {$[16,65]$} \\
\hline C-reactive protein & Fc $\gamma R$ & Neutrophils & Opsonization and phagocytosis & {$[45,47]$} \\
\hline $\begin{array}{l}\text { Surfactant proteins A and D } \\
\text { (SP-A \& SP-D) }\end{array}$ & $\begin{array}{l}\text { Calreticulin-CD91 complex, } \\
\text { C1qR }\end{array}$ & $\begin{array}{c}\text { Neutrophils, } \\
\text { alveolar macrophages }\end{array}$ & Opsonization and conidial agglutination & {$[36]$} \\
\hline $\begin{array}{l}\text { Collectins } 11 \text { and } 12 \\
\text { (CL-K1 \& CL-P1) }\end{array}$ & \multicolumn{2}{|c|}{ No direct binding, but through complement activation } & Binding and activation of lectin complement pathway & {$[38,39]$} \\
\hline Pentraxin, Ptx3 & Through Fc $\gamma$ R and CR3 & Neutrophils & $\begin{array}{l}\text { Opsonization and activation of alternative pathway } \\
\text { Interaction with C1q or ficolin- } 2 \text { to activate classical and } \\
\text { lectin pathways, respectively, thus leading to conidial } \\
\text { opsonization by C3b }\end{array}$ & {$[14,40,64]$} \\
\hline
\end{tabular}




\section{Conclusions}

Soluble mediators of innate immunity are crucial in the recognition of dormant $A$. fumigatus, which has a sophisticated mechanism of masking its immunogenic cell wall polysaccharides by the rodlet and melanin layers. Here in this review, we have summarized the responsible soluble mediators, for which most of them are collectins. Importantly, the ligands for collectin binding remain unidentified. Further investigation of the interaction between these aforementioned collectins and the major components of the rodlet layer, RodA protein, and melanin, should be warranted. It would be worthy to examine all the remaining collectins of their ability to recognize dormant $A$. fumigatus conidia. Surprisingly, the role of immune receptors in the recognition of dormant $A$. fumigatus conidia opsonized by soluble mediators remained unexplored.

Acknowledgments: This study is supported by the bilateral COMASPIN grant from ANR (L'Agence nationale de la recherché; ANR-13-ISV3-0004) France and DST (Department of Science and Technology) India. Sarah Sze Wah Wong was supported by post-doctoral fellowship from this grant.

Author Contributions: Sarah Sze Wah Wong and Vishukumar Aimanianda conceived and wrote the paper.

Conflicts of Interest: The authors declare no conflict of interest.

\section{References}

1. Latgé, J.P. Aspergillus fumigatus and aspergillosis. Clin. Microbiol. Rev. 1999, 12, 310-350. [PubMed]

2. Lee, M.J.; Sheppard, D.C. Recent advances in the understanding of the Aspergillus fumigatus cell wall. J. Microbiol. 2016, 54, 232-242. [CrossRef] [PubMed]

3. Soubani, A.O.; Chandrasekar, P.H. The clinical spectrum of pulmonary aspergillosis. Chest 2002, 121, 1988-1999. [CrossRef] [PubMed]

4. Aimanianda, V.; Bayry, J.; Bozza, S.; Kniemeyer, O.; Perruccio, K.; Elluru, S.R.; Clavaud, C.; Paris, S.; Brakhage, A.A.; Kaveri, S.V.; et al. Surface hydrophobin prevents immune recognition of airborne fungal spores. Nature 2009, 460, 1117-1121. [CrossRef] [PubMed]

5. Aimanianda, V.; Latge, J.P. Fungal hydrophobins form a sheath preventing immune recognition of airborne conidia. Virulence 2010, 1, 185-187. [CrossRef] [PubMed]

6. Latgé, J. Tasting the fungal cell wall. Cell. Microbiol. 2010, 12, 863-872. [CrossRef] [PubMed]

7. Delves, P.; Roitt, I. The immune system. N. Engl. J. Med. 2000, 343, 37-50. [CrossRef] [PubMed]

8. Balloy, V.; Chignard, M. The innate immune response to Aspergillus fumigatus. Microbes. Infect. 2009, 11, 919-927. [CrossRef] [PubMed]

9. Okamoto, T.; Tanida, T.; Wei, B.; Ueta, E.; Yamamoto, T.; Osaki, T. Regulation of fungal infection by a combination of amphotericin B and peptide 2, a lactoferrin peptide that activates neutrophils. Clin. Diagn. Lab. Immunol. 2004, 11, 1111-1119. [CrossRef] [PubMed]

10. Lupetti, A.; van Dissel, J.; Brouwer, C.; Nibbering, P. Human antimicrobial peptides' antifungal activity against Aspergillus fumigatus. Eur. J. Clin. Microbiol. Infect. Dis. 2008, 27, 1125-1129. [CrossRef] [PubMed]

11. Walport, M.J. Complement. N. Engl. J. Med. 2001, 344, 1058-1066. [CrossRef] [PubMed]

12. Ratnoff, W.D.; Fearon, D.T.; Austen, K.F. The role of antibody in the activation of the alternative complement pathway. Springer Semin. Immunopathol. 1983, 6, 361-371. [CrossRef] [PubMed]

13. Fujita, T. Evolution of the lectin-complement pathway and its role in innate immunity. Nat. Rev. Immunol. 2002, 2, 346-353. [CrossRef] [PubMed]

14. Speth, C.; Rambach, G. Complement attack against Aspergillus and corresponding evasion mechanisms. Interdiscip. Perspect. Infect. Dis. 2012, 2012, 463794. [CrossRef] [PubMed]

15. Kozel, T.R.; Wilson, M.A.; Farrell, T.P.; Levitz, S.M. Activation of C3 and binding to Aspergillus fumigatus conidia and hyphae. Infect. Immun. 1989, 57, 3412-3417. [PubMed]

16. Dumestre-Perard, C.; Lamy, B.; Aldebert, D.; Lemaire-Vieille, C.; Grillot, R.; Brion, J.-P.; Gagnon, J.; Cesbron, J.-Y. Aspergillus conidia activate the complement by the mannan-binding lectin $\mathrm{C} 2$ bypass mechanism. J. Immunol. 2008, 181, 7100-7105. [CrossRef] [PubMed] 
17. Braem, S.G.E.; Rooijakkers, S.H.M.; van Kessel, K.P.M.; de Cock, H.; Wösten, H.A.B.; van Strijp, J.A.G.; Haas, P.J.A. Effective neutrophil phagocytosis of Aspergillus fumigatus is mediated by classical pathway complement activation. J. Innate Immun. 2015, 7, 364-374. [CrossRef] [PubMed]

18. Sturtevant, J.E.; Latge, J.P. Interactions between conidia of Aspergillus fumigatus and human complement component C3. Infect. Immun. 1992, 60, 1913-1918. [PubMed]

19. Eddie, W.K.; Kazue, I.; Ezekowitz, T.R.A.; Stuart, L.M.; Ip, W.K.; Takahashi, K.; Ezekowitz, R.A.; Alan, R. Mannose-binding lectin and innate immunity. Immunol. Rev. 2009, 230, 9-21. [CrossRef] [PubMed]

20. Neth, O.; Jack, D.L.; Dodds, A.W.; Holzel, H.; Klein, N.J.; Turner, M.W. Mannose-binding lectin binds to a range of clinically relevant microorganisms and promotes complement deposition. Infect. Immun. 2000, 68, 688-693. [CrossRef] [PubMed]

21. Matsushita, M. Ficolins: Complement-activating lectins involved in innate immunity. J. Innate Immun. 2009, 2, 24-32. [CrossRef] [PubMed]

22. Hummelshøj, T.; Ma, Y.J.; Munthe-Fog, L.; Bjarnsholt, T.; Moser, C.; Skjoedt, M.O.; Romani, L.; Fujita, T.; Endo, Y.; Garred, P. The interaction pattern of murine serum ficolin-A with microorganisms. PLoS ONE 2012, 7, e38196. [CrossRef] [PubMed]

23. Bidula, S.; Sexton, D.W.; Yates, M.; Abdolrasouli, A.; Shah, A.; Wallis, R.; Reed, A.; Armstrong-James, D.; Schelenz, S. H-ficolin binds Aspergillus fumigatus leading to activation of the lectin complement pathway and modulation of lung epithelial immune responses. Immunology 2015, 146, 281-291. [CrossRef] [PubMed]

24. Bidula, S.; Kenawy, H.; Ali, Y.M.; Sexton, D.; Schwaeble, W.J.; Schelenz, S. Role of ficolin-A and lectin complement pathway in the innate defense against pathogenic Aspergillus species. Infect. Immun. 2013, 81, 1730-1740. [CrossRef] [PubMed]

25. Schønheyder, H.; Andersen, P. Complement-binding antibodies to Aspergillus fumigatus in patients with pulmonary aspergillosis. Acta Pathol. Microbiol. Immunol. Scand. B 1983, 91, 1-7. [CrossRef] [PubMed]

26. Rosbjerg, A.; Genster, N.; Pilely, K.; Skjoedt, M.; Stahl, G.L.; Garred, P. Complementary roles of the classical and lectin complement pathways in the defense against Aspergillus fumigatus. Front. Immunol. 2016, 7, 473. [CrossRef] [PubMed]

27. Rosas, Á.L.; MacGill, R.S.; Nosanchuk, J.D.; Kozel, T.R.; Casadevall, A. Activation of the alternative complement pathway by fungal melanins. Clin. Diagn. Lab. Immunol. 2002, 9, 144-148. [CrossRef] [PubMed]

28. Pal, A.K.; Gajjar, D.U.; Vasavada, A.R. DOPA and DHN pathway orchestrate melanin synthesis in Aspergillus species. Med. Mycol. 2014, 52, 10-18. [PubMed]

29. Williamson, P.R.; Wakamatsu, K.; Ito, S.; Williamson, P.R.; Wakamatsu, K. Melanin biosynthesis in Cryptococcus neoformans. J. Bacteriol. 1998, 180, 1570-1572. [PubMed]

30. Youngchim, S.; Morris-Jones, R.; Hay, R.J.; Hamilton, A.J. Production of melanin by Aspergillus fumigatus. J. Med. Microbiol. 2004, 53, 175-181. [CrossRef] [PubMed]

31. Gabay, C.; Kushner, I. Acute-phase proteins and other systemic responses to inflammation. N. Engl. J. Med. 1999, 340, 448-454. [CrossRef] [PubMed]

32. Kishore, U.; Greenhough, T.J.; Waters, P.; Shrive, A.K.; Ghai, R.; Kamran, M.F.; Bernal, A.L.; Reid, K.B.M.; Madan, T.; Chakraborty, T. Surfactant proteins SP-A and SP-D: Structure, function and receptors. Mol. Immunol. 2006, 43, 1293-1315. [CrossRef] [PubMed]

33. McIntosh, J.C.; Swyers, A.H.; Fisher, J.H.; Wright, J.R. Surfactant proteins A and D increase in response to intratracheal lipopolysaccharide. Am. J. Respir. Cell Mol. Biol. 1996, 15, 509-519. [CrossRef] [PubMed]

34. Atochina, E.N.; Beers, M.F.; Tomer, Y.; Scanlon, S.T.; Russo, S.J.; Panettieri, R.A.; Haczku, A. Attenuated allergic airway hyperresponsiveness in C57BL/ 6 mice is associated with enhanced surfactant protein (SP)-D production following allergic sensitization. Respir. Res. 2003, 4, 15. [CrossRef] [PubMed]

35. Madan, T.; Kaur, S.; Saxena, S.; Singh, M.; Kishore, U.; Thiel, S.; Reid, K.B.M.; Sarma, P.U. Role of collectins in innate immunity against aspergillosis. Med. Mycol. 2005, 43, S155-S163. [CrossRef] [PubMed]

36. Madan, T.; Eggleton, P.; Kishore, U.; Strong, P.; Aggrawal, S.S.; Sarma, P.U.; Reid, K.B.M. Binding of pulmonary surfactant proteins $\mathrm{A}$ and $\mathrm{D}$ to Aspergillus fumigatus conidia enhances phagocytosis and killing by human neutrophils and alveolar macrophages. Infect. Immun. 1997, 65, 3171-3179. [PubMed]

37. Allen, M.J.; Harbeck, R.; Smith, B.; Voelker, D.R.; Mason, R.J. Binding of rat and human surfactant proteins A and D to Aspergillus fumigatus conidia. Infect. Immun. 1999, 67, 4563-4569. [PubMed] 
38. Ma, Y.J.; Skjoedt, M.O.; Garred, P. Collectin-11/MASP complex formation triggers activation of the lectin complement pathway-The fifth lectin pathway initiation complex. J. Innate Immun. 2013, 5, 242-250. [CrossRef] [PubMed]

39. Ma, Y.J.; Hein, E.; Munthe-Fog, L.; Skjoedt, M.-O.; Bayarri-Olmos, R.; Romani, L.; Garred, P. Soluble collectin-12 (CL-12) is a pattern recognition molecule initiating complement activation via the alternative pathway. J. Immunol. 2015, 195, 3365-3373. [CrossRef] [PubMed]

40. Moalli, F.; Doni, A.; Deban, L.; Zelante, T.; Zagarella, S.; Bottazzi, B.; Romani, L.; Mantovani, A.; Garlanda, C. Role of complement and $\mathrm{F}_{\mathrm{C}} \gamma$ receptors in the protective activity of the long pentraxin PTX3 against Aspergillus fumigatus. Blood 2010, 116, 5170-5181. [CrossRef] [PubMed]

41. Garlanda, C.; Hirsch, E.; Bozza, S.; Salustri, A.; De Acetis, M.; Nota, R.; Maccagno, A.; Riva, F.; Bottazzi, B.; Peri, G.; et al. Non-redundant role of the long pentraxin PTX3 in anti-fungal innate immune response. Nature 2002, 420, 182-186. [CrossRef] [PubMed]

42. Bottazzi, B.; Vouret-Craviari, V.; Bastone, A.; De Gioia, L.; Matteucci, C.; Peri, G.; Spreafico, F.; Pausa, M.; D'Ettorre, C.; Gianazza, E.; et al. Multimer formation and ligand recognition by the long pentraxin PTX3. J. Biol. Chem. 1997, 272, 32817-32823. [CrossRef] [PubMed]

43. Chai, L.Y.A.; Netea, M.G.; Teerenstra, S.; Earnest, A.; Vonk, A.G.; Schlamm, H.T.; Herbrecht, R.; Troke, P.F.; Kullberg, B. Early proinflammatory cytokines and C-reactive protein trends as predictors of outcome in invasive aspergillosis. J. Infect. Dis. 2010, 202, 1454-1462. [CrossRef] [PubMed]

44. Roques, M.; Chretien, M.L.; Favennec, C.; Lafon, I.; Ferrant, E.; legouge, C.; Plocque, A.; Golfier, C.; Duvillard, L.; Amoureux, L.; et al. Evolution of procalcitonin, C-reactive protein and fibrinogen levels in neutropenic leukaemia patients with invasive pulmonary aspergillosis or mucormycosis. Mycoses 2016, 59, 383-390. [CrossRef] [PubMed]

45. Du Clos, T.W. Function of C-reactive protein. Ann. Med. 2000, 32, 274-278. [CrossRef] [PubMed]

46. Jensen, T.D.B.; Schonheyder, H.; Andersen, P.; Stenderup, A. Binding of C-reactive protein to Aspergillus fumigatus fractions. J. Med. Microbiol. 1986, 21, 173-177. [CrossRef] [PubMed]

47. Richardson, M.D.; Shankland, G.S.; Gray, C.A. Opsonizing activity of C-reactive protein in phagocytosis of Aspergillus fumigatus conidia by human neutrophils. Mycoses 1991, 34, 141-143. [CrossRef] [PubMed]

48. Ross, G.D.; Vĕtvicka, V. CR3 (CD11b, CD18): A phagocyte and NK cell membrane receptor with multiple ligand specificities and functions. Clin. Exp. Immunol. 1993, 92, 181-184. [CrossRef] [PubMed]

49. Myones, B.L.; Dalzell, J.G.; Hogg, N.; Ross, G.D. Neutrophil and monocyte cell surface p150,95 has iC3b-receptor (CR4) activity resembling CR3. J. Clin. Investig. 1988, 82, 640-651. [CrossRef] [PubMed]

50. Xu, S.; Wang, J.; Wang, J.-H.; Springer, T.A. Distinct recognition of complement iC3b by integrins $\alpha X \beta 2$ and aMß2. Proc. Natl. Acad. Sci. USA 2017, 114, 3403-3408. [CrossRef] [PubMed]

51. Ross, G.D. Complement receptors. In Encyclopedia of Immunology, 2nd ed.; Delves, P.J., Ed.; Elsevier: Amsterdam, The Netherlands, 1998; pp. 629-634.

52. Caron, E.; Hall, A. Identification of two distinct mechanisms of phagocytosis controlled by different Rho GTPases. Science 1998, 282, 1717-1721. [CrossRef] [PubMed]

53. Lukácsi, S.; Nagy-Baló, Z.; Erdei, A.; Sándor, N.; Bajtay, Z. The role of CR3 (CD11b/CD18) and CR4 (CD11c/CD18) in complement-mediated phagocytosis and podosome formation by human phagocytes. Immunol. Lett. 2017, 189, 64-72. [CrossRef] [PubMed]

54. Klickstein, L.B.; Barbashov, S.F.; Liu, T.; Jack, R.M.; Nicholson-Weller, A. Complement receptor type 1 (CR1, CD35) is a receptor for C1q. Immunity 1997, 7, 345-355. [CrossRef]

55. Ghiran, I.; Barbashov, S.F.; Klickstein, L.B.; Tas, S.W.; Jensenius, J.C.; Nicholson-Weller, A. Complement receptor $1 / \mathrm{Cd} 35$ is a receptor for mannan-binding lectin. J. Exp. Med. 2000, 192, 1797-1808. [CrossRef] [PubMed]

56. Fällman, M.; Andersson, R.; Andersson, T. Signaling properties of CR3 (CD11b/CD18) and CR1 (CD35) in relation to phagocytosis of complement-opsonized particles. J. Immunol. 1993, 151, 330-338. [PubMed]

57. Philippe, B.; Ibrahim-Granet, O.; Prevost, M.C.; Gougerot-Pocidalo, M.A.; Perez, M.S.; Van der Meeren, A.; Latge, J.P. Killing of Aspergillus fumigatus by alveolar macrophages is mediated by reactive oxidant intermediates. Infect. Immun. 2003, 71, 3034-3042. [CrossRef] [PubMed]

58. Wright, S.D.; Silverstein, S.C. Receptors for C3b and C3bi promote phagocytosis but not the release of toxic oxygen from human phagocytes. J. Exp. Med. 1983, 158, 2016-2023. [CrossRef] [PubMed] 
59. Zhou, M.J.; Brown, E.J. CR3 (Mac-1, alpha M beta 2, CD11b/CD18) and Fc $\gamma$ RIII cooperate in generation of a neutrophil respiratory burst: Requirement for Fc $\gamma$ RIII and tyrosine phosphorylation. J. Cell. Biol. 1994, 125, 1407-1416. [CrossRef] [PubMed]

60. Ogden, C.A.; DeCathelineau, A.; Hoffmann, P.R.; Bratton, D.; Ghebrehiwet, B.; Fadok, V.A.; Henson, P.M. $\mathrm{C} 1 \mathrm{q}$ and mannose binding lectin engagement of cell surface calreticulin and CD91 initiates macropinocytosis and uptake of apoptotic cells. J. Exp. Med. 2001, 194, 781-796. [CrossRef] [PubMed]

61. Vandivier, R.W.; Ogden, C.A.; Fadok, V.A.; Hoffmann, P.R.; Brown, K.K.; Botto, M.; Walport, M.J.; Fisher, J.H.; Henson, P.M.; Greene, K.E. Role of surfactant proteins A, D, and C1q in the clearance of apoptotic cells in vivo and in vitro: Calreticulin and CD91 as a common collectin receptor complex. J. Immunol. 2002, 169, 3978-3986. [CrossRef] [PubMed]

62. Gardai, S.J.; Xiao, Y.Q.; Dickinson, M.; Nick, J.A.; Voelker, D.R.; Greene, K.E.; Henson, P.M. By binding SIRPalpha or calreticulin/CD91, lung collectins act as dual function surveillance molecules to suppress or enhance inflammation. Cell 2003, 115, 13-23. [CrossRef]

63. Bobak, D.A.; Frank, M.M.; Tenner, A.J. Characterization of C1q receptor expression on human phagocytic cells: Effects of PDBu and fMLP. J. Immunol. 1986, 136, 4604-4610. [PubMed]

64. Ma, Y.J.; Doni, A.; Hummelshøj, T.; Honoré, C.; Bastone, A.; Mantovani, A.; Thielens, N.M.; Garred, P. Synergy between ficolin-2 and pentraxin 3 boosts innate immune recognition and complement deposition. J. Biol. Chem. 2009, 284, 28263-28275. [CrossRef] [PubMed]

65. Rosbjerg, A.; Genster, N.; Hansen, K.P.; Skjoedt, M.-O.; Gal, P.; Stahl, G.L.; Garred, P. Mannose-binding lectin (MBL) is the main complement activator on Aspergillus fumigatus conidia under immunocompromised conditions. J. Immunol. 2016, 196 (1 supplement), 63.6.

(C) 2017 by the authors. Licensee MDPI, Basel, Switzerland. This article is an open access article distributed under the terms and conditions of the Creative Commons Attribution (CC BY) license (http:/ / creativecommons.org/licenses/by/4.0/). 